\title{
Are Capabilities Compatible with Po- litical Liberalism? A Third Way
}

\author{
THOM BROOKS \\ Durham Law School, Durham, United Kingdom
}

\begin{abstract}
This article explores the relationship between capabilities and political liberalism. There are two views about how they might be compatible: Sen claims capabilities should be seen as a revision of primary goods while Nussbaum argues capabilities should form part of an overlapping consensus. It is argued they are both right-and incorrect. Whereas Sen identifies where compatibility might best be found, it is Nussbaum's conception of capabilities that is able to overcome Rawls's objections to Sen's proposal. This provides a new third way of conceiving how capabilities and political liberalism might address these concerns that is more compelling for how Sen and Nussbaum claim. The two rivals can come together, but not in the way that either of its most well known champions have argued.
\end{abstract}

Keywords: Capabilities; overlapping consensus; political liberalism; primary goods.

\section{Introduction}

It is striking that the leading proponents of the capabilities approachAmartya Sen and Martha Nussbaum-each see their distinctive approach as compatible with John Rawls's political liberalism and not as an alternative to it. ${ }^{1}$ Interestingly, both Sen and Nussbaum each see the compatibility of capabilities with political liberalism in very different ways. While Sen argues that his view of capabilities are best

${ }^{1}$ While Amartya Sen speaks of his capability approach and Nussbaum of her capabilities approach, I will use 'capabilities approach' to capture them both unless otherwise noted. 
incorporated within Rawls's primary goods, Nussbaum claims that her different view of capabilities are better understood as forming part of an overlapping consensus.

This article considers Rawls's political liberalism and these different views on capabilities claim to locate themselves as a part of political liberalism in very different ways. It is argued that neither of these two models is successful and, instead, a new third option is more promising that lies between them. My claim is that Nussbaum's approach fits better with political liberalism, but only in the place that Sen locates for his own approach. Sen and Nussbaum are correct to highlight the compatibility of the capabilities approach with political liberalism, but not about how or where either find these two compatible. Instead, uniting capabilities and political liberalism is only possible through this new, third way which Rawls and they have overlooked.

The structure of my argument is as follows. I begin by describing Rawls's political liberalism before proceeding to discuss how Sen believed his capability approach is compatible with it. I then explain Nussbaum's arguments about how her approach is compatible with Rawls's political liberalism. The final section critically examines their claims and argues for a new third way bringing together elements from each showing why this different view is more compelling and overcomes objections that Rawls has about the relationship between political liberalism and capabilities.

\section{Political liberalism}

John Rawls (1996: xviii, see 3-4) came to believe that his A Theory of Justice suffered from a 'serious problem' concerning political stability. He recognized that citizens are deeply divided by reasonable and potentially incompatible religious, philosophical or moral comprehensive doctrines (Rawls 1996: 13, 168; Rawls 2001a: 193). ${ }^{2}$ This 'fact of reasonable pluralism' about the 'reasonable comprehensive doctrines' that citizens have is neither exceptional nor rare, but an inescapable and ineliminable fact about democratic societies (Rawls 1996: 24-25n227, 63-64, 129, 140, 144, 147-48, 172; Rawls 1999: 131; Rawls 2001aa: 3-4, $33-34,36,40,84)$. We cannot wish our reasonable differences away.

Reasonable pluralism presents a potential threat to political stability because if citizens are to be free and equal-as Rawls presupposes-their reasonable disagreement about preferences for different and opposing comprehensive doctrines can undermine political stability over time. This creates a problem for how political stability may be possible without denying the equality of citizens. Rawls formulates the challenge like this: 'How is it possible that deeply opposed though reasonable comprehensive doctrines may live together and all affirm the

2 Rawls's political liberalism rejects our taking account of unreasonable comprehensive doctrines. I will use 'reasonable comprehensive doctrines' and 'comprehensive doctrines' interchangeably. 
political conception of a constitutional regime? What is the structure and content of a political conception that can gain the support of such an overlapping consensus?' (Rawls 1996: xx)

For Rawls, disagreement about comprehensive doctrines matters. The public can be divided about whether their political community should support policies like capital punishment or criminalizing euthanasia without exception from the comprehensive doctrines they endorse. ${ }^{3}$ Rawls's political liberalism respect the equality of citizens by forbidding our prioritizing any one comprehensive doctrine over others. Otherwise, the doctrines held by some citizens would have a privileged political status above the doctrines held by others-and their equality would be respected. This creates the need to find some way to strike this delicate and potentially complex balance.

Rawls argues that it is a fact that different citizens will endorse a range of different reasonable comprehensive doctrines. This fact of reasonable pluralism poses a threat to political stability over time requires a solution-otherwise, political stability over time will be very difficult, if not impossible, to maintain. Rawls argues that citizens must have a way to determine political judgements acceptable to all while treating all reasonable comprehensive doctrines on an equal footing to respect the equality of citizens. He says:

Thus I believe that a democratic society is not and cannot be a community, where by a community I mean a body of persons united in affirming the same comprehensive, or partially comprehensive, doctrine the fact of reasonable pluralism which characterizes a society with free institutions makes this impossible. (Rawls 2001a: 3)

So disagreement over comprehensive doctrines is not to be addressed by privileging one over others or by aiming to have all citizens affirm doctrine. We must find some other way to navigate reasonable pluralism.

Rawls's solution is to defend the idea of an overlapping consensus (Rawls 2001a: 32-38; Rawls 1996: 133-72; see Freeman 2007: 366-71; Maffetone 2010: 261-74; Scanlon 2003: 159-61). This consensus is a common platform that all citizens can accept no matter which comprehensive doctrine they endorse. The consensus is conceived as a 'political conception of justice' (Rawls 2001a: 20). For Rawls, the threat to political stability posed by reasonable pluralism is 'a problem of political justice, not a problem about the highest good' and so requires a 'political' solution (Rawls 1996: xxvii, see 140).

An overlapping consensus is a shared political conception of justice that citizens can reasonable accept irrespective of which comprehensive doctrine they endorse. Rawls says that 'political liberalism looks for a political conception of justice that we hope can gain the support of an overlapping consensus of reasonable religious, philosophical, and moral doctrines' (Rawls 1996: 10). Citizens can affirm an overlapping

\footnotetext{
${ }^{3}$ For example, on capital punishment see Brooks 2004; Brooks 2011.
} 
consensus as reasonable without rejecting their acceptance of any reasonable comprehensive doctrine.

They create a consensus through the use of public reasons. These reasons are claims we may reasonably offer to others for mutual acceptance available to every citizen (Rawls 2001b: 208). We can contrast public reasons with non-public reasons (Rawls 2001a: 92; Rawls 1996: $213,220-22)$. The latter are reasons that might be acceptable to some, but not all, comprehensive doctrines. For example, providing a reason to endorse or reject a public policy because of the view of an organized religion's doctrine is a non-public reason because its acceptance requires our support for a particular religion's authority on that matter-and so incompatible with other reasonable comprehensive doctrines citizens may endorse (Rawls 1999: 169-70; Rawls 1996: lv-lvii). An overlapping consensus is only possible when all citizens can reasonably accept the public reasons offered to justify a political conception of justice all can support notwithstanding their reasonable differences. Public reasons may not settle all, or almost all, political questions we face. However, for Rawls, they are the only reasons we have to perform this important task (Rawls 2001a: 26-27, 91; Rawls 1996: 163).

An overlapping consensus built on public reasons creates a shared political conception of justice without setting up a new, rival comprehensive view (Rawls 1996: xxix). A consensus is freestanding because its acceptance does not entail any special commitment to any particular doctrine (Rawls 2001a: 33, 37; Rawls 1996: 13). In this way, Rawls claims that an overlapping consensus justifies political stability 'for the right reasons' as it respects the equality of citizens and their reasonable differences over the good (Rawls 1996: xxxix, xli-xliii).

\section{Sen on political liberalism}

Rawls's proposal of political liberalism as a solution to the problem of political stability in light of reasonable pluralism has attracted criticism. Some, such as Kurt Baier (1989), Brian Barry (1995) and George Klosko (1994), have argued that political liberalism's overlapping consensus is unnecessary for securing political stability. They argue that there are resources in Rawls's theory of justice-such as a commitment to two principles of justice - that can forge stability despite disagreements about the good. Others like Kent Greenawalt (1995), Michael Sandel (1994) and Leif Wenar (1995) claim an overlapping consensus is too fragile to secure political stability. They accept that the consensus is an important bridge connecting citizens across their reasonable differences over the good, but skeptical about how strong the ties that bind them together can be. In previous work, I have argued that we can accept both sides: Rawls does have resources in his theory to build solidarity beyond what others have identified, such as reciprocity, that can strengthen the ties that an overlapping consensus offers (Brooks 2012).

One especially interesting line of criticism comes from proponents 
of the capabilities approach claiming that Rawls's political liberalism can be improved by incorporating capabilities into his account. How his political liberalism might be compatible with capabilities will be the subject for the rest of our discussion.

Amartya Sen argues Rawls's list of primary goods are best understood in terms of Sen's understanding of capability and so he should revise his list accordingly (Sen 1985: 199-201, see Nussbaum 2006: 141; Nussbaum 2000: 68; Scanlon 2009: 197-99). In contrast, Rawls claims that citizens must be guaranteed primary goods above a social minimum. These primary goods are defined as 'what persons need in their status as free and equal persons, and as normal and fully cooperating members of society over a complete life' (Rawls 1971: xiii). These goods include the following:

A. Basic rights and liberties, also given by a list;

B. Freedom of movement and free choice of occupation against a background of diverse opportunities;

C. Powers and prerogatives of offices and positions of responsibility in the political and economic institutions of the basic structure;

D. Income and wealth; and finally,

E. The social bases of self-respect. (Rawls 1996: 181)

If a state is unable to guarantee a social minimum of these primary goods, then it fails to satisfy the constitutional essentials of a just polity (Rawls 1996: 228-29). This is because our capacity to understand, to apply and to act from-and not merely be in accordance with-the principles of political justice require a social minimum is achieved and makes possible what Rawls calls 'a decent human life' (Rawls 2001a: 18-19, 129).

Sen argues that Rawls should revise this account of primary goods to remove a problematic ambiguity at its centre that would help clarify their role in securing individual freedom and well-being (Sen 1999: 56; Sen 1995: 33; Sen 2008: 24-25; Sen 2009: 238). Sen says:

Some primary goods (such as "income and wealth") are no more than means to real ends ... Other primary goods (such as "the social basis of self-respect" to which Rawls makes an explicit reference) can include aspects of the social climate, even though they are generalized means (in the case of "the social basis of self-respect" means to achieving self-respect). Still others (such as "liberties") can be interpreted in different ways: either as a means (liberties permit us to do things that we may value doing) or as the actual freedom to achieve certain results. (Sen 1999: 306-7)

Sen's argument is that Rawls understands primary goods too narrowly_as a means to satisfactory human living, but not its end (Sen 2009: 234). The problem with primary goods, for Sen, is that they fail to capture an important distinction between our 'doing something' and our 'being free to do that thing' (Sen 2009: 234, 237).

Sen argues this problem can be solved by revising Rawls's account of primary goods to become capabilities (Sen 1995: 87; Sen 2009: 64). 
Sen claims that this would 'not be a foundational departure from Rawls's own programme, but mainly an adjustment' (Sen 2009: 66). This is because, for Sen, 'basic capabilities can be seen as a natural extension of Rawls's concern with primary goods'-and a more robust account of them (Sen 1980: 218-19; see Sen 1999: 74, 78; Sen 2009: 262). Rawls should have recognized that institutions are not always required to secure primary goods in some cases: understanding them as capabilities would correct this mistake (Sen 2009: 90).

In summary, Sen claims that Rawls's political liberalism can be compatible with capabilities. Sen argues that capabilities provide a more robust-and more consistent-understanding of primary goods within Rawls's theory. If we revise Rawls's account of primary goods, we can fit capabilities into his political liberalism and close gaps and inconsistencies in Rawls's account.

\section{Nussbaum on political liberalism}

Martha Nussbaum also argues that Rawls's political liberalism is compatible with her own approach to capabilities-which is in a different way from Sen's (Nussbaum 2006: chpts 1-3; Nussbaum 2000: 5, 14, 59, 4-75, 105; Nussbaum 2011: 19, 79, 89-93, 182). Where Sen believes his capability approach can be best incorporated as an improved modification of Rawls's primary goods, Nussbaum claims her capabilities approach can be a part of an overlapping consensus-and so her different conception of capabilities is argued to fit best in a different part of political liberalism.

Nussbaum disagrees with Sen about understanding primary goods as capabilities because she believes it could jeopardize the 'desired simplicity' that Rawls aspired to with his theory of justice 'both in indexing relative social positions and in describing the point of social cooperation' (Nussbaum 2006: 142). While she acknowledges that perhaps Rawls's theory could be made more compelling, it would come at a cost-so Sen is incorrect to argue that Rawls should accept this revision even if there is good reason for him to accept it. ${ }^{4}$

Moreover, Nussbaum claims that if Rawls made this revision it 'would require a major overhaul of the theory [of justice], particularly as a theory of economic justice' (Nussbaum 2006: 146). For Nussbaum, individual decisions about conceptions of the good are left by Rawls to citizens whereas the capabilities approach endorses a shared, public conception of justice where the good of others is built into the good of each citizen (Nussbaum 2006: 158). Furthermore, capabilities are not merely instrumental to human dignity, but 'as ways of realizing a life

${ }^{4} \mathrm{I}$ find this criticism unconvincing because it is unclear that any rendering of capabilities—such as a list like Nussbaum's—-would jeopardize desired simplicity in a list like Rawls's. This criticism may be aimed at a particular understanding of capability, namely, Sen's, but does not clearly concern alternative understandings about capabilities. 
with human dignity' (Nussbaum 2006: 161). The right and the good are inseparable and they 'seem thoroughly intertwined' (Nussbaum 2006: 162-63). Capabilities are 'fundamental entitlements of citizens' and all capabilities are 'necessary for a decent and dignified human life': 'If people are below the threshold on any of the capabilities, that is a failure of basic justice, no matter how high they are on all the others' (Nussbaum 2006: 166-67; see Nussbaum 2000: 73; Nussbaum 2011: 36). In short, while Nussbaum recognizes the potential overlap between primary goods and capabilities identified by Sen, she rejects it as it largely leaves Rawls's contractarianism intact whereas capabilities are 'fundamental entitlements' that must be secured.

She argues that capabilities 'can become the object of an overlapping consensus among people who otherwise have very different comprehensive conceptions of the good' (Nussbaum 2006: 70). Nussbaum says:

The political principles of the capabilities approach are supported by independent arguments about human dignity. We do not try to generate principles out of compassion alone, but, instead, we seek to support them and render them stable through the development of a compassion that is attuned to the political principles for which we have argued. (Nussbaum 2006: 91)

For Nussbaum, capabilities can be part of an overlapping consensus because both enjoy a freestanding justification and she claims capabilities are compatible with any reasonable comprehensive doctrine (Nussbaum 2006: 79, 304-5; Nussbaum 2011: 89-92). While she provides a list of ten capabilities, Nussbaum is also very clear that the list is not 'final' nor set in stone: 'if it turns out to lack something that experience shows to be a crucial element of a life worthy of human dignity, it can always be contested and remade' (Nussbaum 2011: 15).

In summary, Sen claims that Rawls should revise his account of primary goods to conform to Sen's views of capability-Sen claims this would improve Rawls's account and show how capabilities and political liberalism can be made compatible. Nussbaum claims that Rawls should look to capabilities as a part of any overlapping consensus and that this is the best space to bring capabilities and political liberalism together. She argues that capabilities can fulfil the function of an overlapping consensus because any reasonable comprehensive doctrine can connect and support with capabilities. So Sen is correct to claim capabilities and political liberalism are compatible, while Nussbaum claims they are compatible in a different part of Rawls's theory (e.g., an overlapping consensus) than argued for by Sen (e.g., primary goods). They cannot both be correct.

\section{A third way}

I believe Sen and Nussbaum are both correct to argue Rawls's political liberalism is compatible with capabilities, but not in the way that either Sen or Nussbaum claims. Sen is correct that capabilities are best 
placed as a more robust modification of primary goods, but Nussbaum's understanding of capabilities are more compatible with Rawls's theory of justice to serve as this modification. In short, Sen identifies where capabilities should be located and Nussbaum provides the better fitting view of capabilities to fulfil this role-but not vice versa.

To begin, Rawls considers and rejects Sen's proposed revision, but the reason for this rejection is illuminating. Rawls recognizes the significant overlap across his account of primary goods and Sen's account of capability. The issue is that the latter is broader, but in a problematic way. Rawls notes that 'I hope that now our views are in accord on the topics that concern us here, though his view has more broader aims than mine' (Rawls 1996: 179). Rawls says that 'I agree with Sen that basic capabilities are of first importance and that the use of primary goods is always to be assessed in the light of assumptions about those capabilities' (Rawls 1996: 183). However, Rawls argues:

In reply, it should be stressed that the account of primary goods does take into account, and does not abstract from, basic capabilities: namely, the capabilities of citizens as free and equal persons in virtue of their two moral powers. It is these powers that enable them to be normal, and fully cooperating members of society over a complete life and to maintain their status as free and equal citizens ... These remarks locate the role of primary goods within the framework of justice as fairness as a whole ... we see that it does recognize the fundamental relation between primary goods and persons' basic capabilities. In fact, the index of those goods is drawn up by asking what things, given the basic capabilities included in the (normative) conception of citizens as free and equal. (Rawls 2001a: 169-70)

Rawls argues that 'Sen might accept the use of primary goods, at least in many instances': primary goods already incorporate some substantive connection with capabilities that does not require further revision (Rawls 2001a: 170). Primary goods have flexibility in application even if not explicitly open to future revision over time and changing circumstances.

However, the difference is that primary goods are more determinate and easier to apply than capabilities (Rawls 1996: 185). Rawls says: 'A scientific (as opposed to a normative) measure of the full range of these capabilities is impossible as a matter of practice, if not theoretically as well' (Rawls 2001a: 171). For Rawls, concepts, such as 'well-being', are 'not sufficiently determinate' (Rawls 1971: 283; see Cohen 2011: 40-43, 47-48. 50-51). Primary goods are more attractive because they offer an account that speaks to some measure of well-being in a way that is more relevant for application to practices. Primary goods, not capabilities, satisfy the publicity criterion whereby claims of injustice are easily accessible and verifiable by all.

This criticism of Sen's account is much less of a problem for Nussbaum's account of capabilities as it presents a list. So one criticism of the capabilities approach is that it is too imprecise and does not offer 'workable criteria for interpersonal comparisons that can be publicly 
and, if possible, easily applied' (Rawls 1996: 186). This objection can be overcome by defending a more determinate account of capabilitieslike Nussbaum's - that avoids this problem.

For Rawls, every citizen is guaranteed a social minimum of primary goods. These include (a) basic rights and liberties, (b) freedom of movement and choice of occupation, (c) political and economic freedoms, (d) income and wealth and (e) 'the social bases of self-respect' (Rawls 1996: 181). Thus primary goods represent a package of essential rights and freedoms, opportunities, basic needs and self-respect.

Nussbaum's capabilities approach captures this conception in a more robust alternative form. Her proposed list of ten capabilities includes Life; Bodily Health; Bodily Integrity; Senses, Imagination, Thought; Emotions; Practical Reason; Affiliation; Other Species; Play and Control Over One's Environment. ${ }^{5}$ Neither Nussbaum's capabilities approach nor Rawls's social minimum are meant to offer a complete account of social justice-although both claim to provide us with an essential component for any such account of 'minimum core social entitlements' (Rawls 1971: 244-45, 279; Nussbaum 2006: 75).

Capabilities and the social minimum address the same primary goods, but capabilities provides more clarity_or what Nussbaum calls 'a rather ample social minimum' (Nussbaum 2011: 40). While both capture a minimum of basic rights and liberties, only the capabilities approach is explicit in its relationship to human rights and rights more generally (Nussbaum 2006: 78; Nussbaum 2011: 62). They each address freedom of movement and occupational choice, yet capabilities develops greater specification of their importance for human flourishing and related goods, such as affiliation, recreation and some measure of control over political and material environments. Thus capabilitiesas understood by Nussbaum-do not merely map onto primary goods, but the former provide an extended view of the latter. Nussbaum's list of capabilities is a better fit with Rawls's list of primary goods than Sen's capability approach which eschews such lists and does not focus on the need to satisfy a threshold minimum like Nussbaum's capabilities approach and Rawls's social minimum of primary goods does.

The second and more crucial reason why Rawls rejects Sens's proposed revision of the primary goods as capabilities is because Rawls understood capabilities as a kind of comprehensive doctrine. Rawls argues that political liberalism 'presupposes no particular comprehensive view, and hence may be supported by an enduring overlapping consensus of reasonable doctrines' (Rawls 2001a: 37). Rawls believes that primary goods have a more limited nature than capabilities. These goods are understood within a political conception of justice that address the needs of citizens and 'not anyone's idea of the basic values of human life and must not be so understood' (Rawls 1996: 188). Rawls says: 'Justice as fairness rejects the idea of comparing and maximizing overall

${ }^{5}$ On Nussbaum's list, see Brooks 2020. 
well-being in matters of political justice': primary goods should not be understood in terms of 'anyone's idea of the basic values of human life ... however essential their possession' (Rawls 1996: 188). Political liberalism would then best respect the fact of reasonable pluralism and endorse a political conception 'that is mutually acceptable to citizens generally' (Rawls 1996: 188).

The problem with this objection is that it assumes without argument that the capabilities approach is an overly substantive view about the good that a person might reasonably reject. The primary goods are compatible with any reasonable comprehensive doctrine. So Rawls cannot be opposed to any endorsement of goods for fear that they might be incompatible with reasonable pluralism without denying primary goods altogether. Rawls is clear that primary goods overlap to some substantial degree with capabilities, such as the need to secure the guarantee of moral powers for each individual. Rawls appears to claim that primary goods are different from capabilities because they provide a sufficiently 'thin' conception of the good endorsable by all reasonable persons. Primary goods are a sufficiently thin conception because they are compatible with any reasonable comprehensive doctrine. But what Rawls needs to argue is not that primary goods are sufficiently thin, but rather that capabilities are too 'thick': the issue is then not whether capabilities are more robust than primary goods, but incompatible with any reasonable doctrine. If they are not, then his objection fails-and it does fail. The capabilities approach is not a fully comprehensive doctrine as even its leading critics accept (Pogge 2010: 19-20).

Rawls's concern is directed towards a specific understanding of capability, namely, Sen's approach. This is a more 'thick' conception than Nussbaum's insofar as only the latter has a particular focus on satisfying a threshold in a manner not dissimilar to how Rawls employs primary goods and their social minimum. This minimum is potentially compatible for all in a way that a view of capability without specified thresholds does not. In this way, Nussbaum's list makes a better fit with Rawls's list without importing a full comprehensive doctrine-a risk that Rawls thought possible with Sen's capability approach.

However, Nussbaum did not accept Sen's view that capabilities are best incorporated into political liberalism as a revised view of primary goods, but instead as part of an overlapping consensus, she acknowledges the close connection between her list of capabilities and Rawls's primary goods and she says her list 'could figure as an account of primary goods' (Nussbaum 2006: 116, see Nussbaum 2000: 5, 74-75). But she could also have noted a further substantive connection between capabilities and primary goods in that both are understood in terms of threshold satisfaction: what matters for Nussbaum is that opportunities to exercise capabilities above a threshold can obtain and what matters for Rawls is primary goods can be enjoyed above a social minimum. As Nussbaum notes, 'the notion of a threshold is more important in my account than the notion of full capability equality' (Nussbaum 2000: 
12). We look to ensuring we are all above a threshold as a fundamental concern of justice for every individual without trade-offs between capabilities-and likewise between primary goods. For these reasons, Nussbaum's account of capabilities seems the better fit despite her reservations about revising Rawls's primary goods in terms of capabilities.

Nussbaum's argument for understanding capabilities as part of an overlapping consensus is problematic-and because of the specific content she builds into her capabilities. For example, the capability of Bodily Integrity includes a right to 'choice in matters of reproduction' (Nussbaum 1999: 41). If her capabilities approach is to be a part of an overlapping consensus, then it must be acceptable to any reasonable comprehensive doctrine-and these doctrines include all major world faiths (Rawls 1996: 59). The problem here is not that Bodily Integrity is a capability, but that Bodily Integrity is given with the specific content of providing for a right to reproductive choice. This is because not all major world religions-Roman Catholicism as only one of several examples-would accept this right upfront. It is possible through the use of public reasons to make the argument for reproductive choice in a way that Catholics could access-perhaps even on grounds of Bodily Integrity - even if most, it not all, did not find these reasons compelling. The possibility of Catholicism does not rule out the community's acceptance of reproductive rights, but any acceptance will need to be achieved through public reasons and not assumed-or given-through a foundation built on an overlapping consensus with parts prima facie objectionable to Catholics. Nussbaum's problem is easily avoided by not so narrowing construing this capability in a way that cannot be accepted by every reasonable comprehensive doctrine.

There are also more controversial issues regarding other capabilities. Another capability on Nussbaum's list is Play which provides individuals with a minimum right 'to enjoy recreational activities' (Nussbaum 1999: 41-42). All citizens are guaranteed at least a minimum to ensure each has a minimally decent life. However, not all major world religions accept leisure as a good-including the Puritans who helped found America. ${ }^{6}$ They may be wrong about the importance of play, but this is to be weighed up-in Rawls's political liberalism-through the interplay of public reason and not a given upfront.

In summary, Nussbaum's capabilities are provided with content that may clash with central tenets of the major world religions included in Rawls's list of reasonable comprehensive doctrines. It is clear that each can have their objections to policies over reproductive choice or leisure activities through the interplay of public reason. However, the content of Nussbaum's capabilities seems to close off this conversation before it begins. Perhaps if left more 'thin' and specified more minimally there would be less concern. As stated, the content of Nussbaum's capabilities does not make obvious their being automatically a part

${ }^{6}$ I am grateful to Derek Matravers for raising this objection to me. 
of any reasonable comprehensive doctrine. So while the list provides a more robust list of primary goods that we might accept in an original position, her list seems too thick to be accepted as an overlapping consensus by individuals from any comprehensive doctrine. Nussbaum is correct that capabilities can be compatible with Rawls's political liberalism and she offers an account that can achieve this result, but not where she thought (e.g., overlapping consensus) but instead somewhere else (e.g., primary goods).

\section{Conclusion}

This article has explored the relationship between capabilities and political liberalism. Both Amartya Sen and Martha Nussbaum argue that their different views on capabilities are compatible with political liberalism in different places. Sen claims capabilities should be seen as a revision of primary goods while Nussbaum argues capabilities should form part of an overlapping consensus.

I have argued that they are both right-and incorrect. Sen correctly identifies where capabilities and political liberalism are most compatible. While Rawls raises objections specifically about how Sen's capability approach is too 'thick' and closer to a comprehensive doctrine, these objections can be met by Nussbaum's capabilities approach which is more 'thin', uses a list, focuses on meeting a minimum threshold and so a more ready fit with Rawls's list of primary goods. So Sen is correct about where to find compatibility, but it is Nussbaum who has the capabilities approach that is the most compatible at that specific point.

Nussbaum argues compatibility between capabilities and political liberalism is best found in an overlapping consensus. However, I have argued that the content of her capabilities is problematic as it includes a core that clashes with the reasonable comprehensive doctrines that should be able to accept it. This is not to say that Nussbaum is mistaken to argue for a right to reproductive choice or for leisure. But it is to say that, on Rawls's account, such content is problematic for prioritizing some doctrines over others. While Nussbaum is correct that capabilities and political liberalism are compatible, I do not agree this is found in the location she identifies.

This article has not considered the merits of bringing capabilities and political liberalism, such as how political stability might be better secured over time as I have argued elsewhere (Brooks 2015). It is clear that capabilities and political liberalism need not be viewed as rivals, but can be brought together except only not how or where Sen and Nussbaum thought- using Nussbaum's list in where Sen identified compatibility in Rawls's primary goods. Thus we need to look for a third way fusing the two to render this compatibility possible. ${ }^{7}$

7 Many thanks to Maria Dimova-Cookson, Peter Jones, Pauline Kleingeld, Martha Nussbaum, Avital Simhony and Martin van Rees for constructive comments on earlier drafts. 


\section{References}

Baier, K. 1989. "Justice and the Aims of Political Philosophy." Ethics 99: 771-90.

Barry, B. 1995. "John Rawls and the Search for Stability." Ethics 105: $874-915$.

Brooks, T. 2004. "Retributivist Arguments against Capital Punishment." Journal of Social Philosophy 35: 188-97.

Brooks, T. 2011. "Retribution and Capital Punishment." In M. D. White (ed.). Retributivism: Essays on Theory and Practice. Oxford: Oxford University Press: $232-45$.

Brooks, T. 2012. "Reciprocity as Mutual Recognition." The Good Society 21: $21-35$.

Brooks, T. 2015. "The Capabilities Approach and Political Liberalism.” In T. Brooks and M. C. Nussbaum (eds.). Rawls's Political Liberalism. New York: Columbia University Press: 139-73.

Brooks, T. 2020. "Capabilities, Freedom and Severe Poverty." In T. Brooks (ed.). The Oxford Handbook of Global Justice. Oxford: Oxford University Press:199-213.

Cohen, G. A. 2011. On the Currency of Egalitarian Justice and Other Essays in Political Philosophy. Princeton: Princeton University Press.

Freeman, S. 2007. Rawls. London: Routledge.

Greenawalt, K. 1995. "Some Problems with Public Reason in John Rawls's Political Liberalism." Loyola of Los Angeles Law Review 28: 1303-17.

Klosko, G. 1994. "Rawls's Argument from Political Stability." Columbia Law Review 94: 1882-97.

Maffetone, S. 2010. Rawls: An Introduction. Cambridge: Polity.

Nussbaum, M. C. 1999. Sex and Social Justice. Oxford: Oxford University Press.

Nussbaum, M. C. 2000. Women and Human Development: The Capabilities Approach. Cambridge: Cambridge University Press.

Nussbaum, M. C. 2006. Frontiers of Justice: Disability, Nationality, Species Membership. Cambridge: Belknap/Harvard University Press.

Nussbaum, M. C. 2011. Creating Capabilities: The Human Development Approach. Cambridge: Belknap/Harvard University Press.

Pogge, T. 2010. "A Critique of the Capabilities Approach.” In H. Brighouse and I. Robeyns (eds), Measuring Justice: Primary Goods and Capabilities. Cambridge: Cambridge University Press: 17-60.

Rawls, J. 1971. A Theory of Justice. Cambridge: Harvard University Press. Rawls, J. 1996. Political Liberalism. New York: Columbia University Press. Rawls, J. 1999. The Law of Peoples. Cambridge: Harvard University Press. Rawls, J. 2001a. Justice as Fairness: A Restatement. Cambridge: Harvard University Press.

Rawls, J. 2001b. "Justice as Fairness." In Collected Papers. Cambridge: Harvard University Press: 47-72.

Sandel, M. 1994. "Political Liberalism." Harvard Law Review 107: 1765-94.

Scanlon, T. M. 2003. "Rawls on Justification." In S. Freeman (ed.). The Cambridge Companion to Rawls. Cambridge: Cambridge University Press: 139-67. 
Scanlon, T. M. 2009. "Value, Desire and Quality of Life." In M. C. Nussbaum and A. Sen (eds.). The Quality of Life. Oxford: Oxford University Press: $185-200$.

Sen, A. 1980. Equality of What? Cambridge: Cambridge University Press.

Sen, A. 1985. "Well-being, Agency and Freedom: The Dewey Lectures 1984." Journal of Philosophy LXXXII: 169-221.

Sen, A. 1995. Inequality Reexamined. Oxford: Oxford University Press.

Sen, A. 1999. Development as Freedom. Oxford: Oxford University Press.

Sen, A. 2008. "The Economies of Happiness and Capability." In L. Bruni, F. Comim and M. Pugno (eds). Capabilities and Happiness. Oxford: Oxford University Press: 16-27.

Sen, A. 2009. The Idea of Justice. London: Allen Lane.

Wenar, L. 1995. "Political Liberalism: An Internal Critique." Ethics 106: 32-62 